\title{
Evaluation of the association between subconjunctival orbital fat prolapse and thyroid-associated orbitopathy
}

This article was published in the following Dove Press journal:

Clinical Interventions in Aging

16 March 2017

Number of times this article has been viewed

\section{Sang Beom Han}

Department of Ophthalmology, Kangwon National University Hospital, Kangwon National University Graduate School of

Medicine, Chuncheon, Korea
Correspondence: Sang Beom Han Department of Ophthalmology, Kangwon National University Hospital, I56 Baengnyeong-ro, Chuncheon, Kangwon 200-722, Korea

$\mathrm{Tel}+82332589210$

Fax +82 332582296

Email m.sangbeom.han@gmail.com

\section{Dear editor}

I read with interest the article entitled "Subconjunctival orbital fat prolapse and thyroid associated orbitopathy: a clinical association" by Chatzistefanou et al. ${ }^{1}$ The case-series study was undoubtedly well designed and conducted, in which the authors successfully revealed that subconjunctival orbital fat prolapse may occasionally be a predominant clinical manifestation of thyroid-associated orbitopathy (TAO) and suggested that the presence of subconjunctival orbital fat prolapse can alert the diagnosis of thyroid orbitopathy.

However, I would like to point out that the mechanism underlying the association between the two conditions is still unclear. Subconjunctival fat prolapse is usually caused by forward herniation of intraconal fat tissue due to dehiscence of tenon capsule precipitated by aging process or trauma. ${ }^{2}$ In TAO, swelling and inflammation of orbital fat can lead to separation of the orbital septum from the capsulopalpebral fascia, which can cause fat prolapse into the orbit. ${ }^{3}$ Previous studies showed that intraorbital inflammation in TAO can lead to apical crowding in orbit and intracranial fat prolapse. ${ }^{4,5}$ Therefore, as the authors postulated, it would be plausible that elevated intraorbital pressure and increase in orbital fat in TAO can also allow anterior herniation of intraorbital fat.

Increased orbital fat and raised intraorbital pressure can also precipitate backward herniation of intraorbital fat into intracranial space and compressive optic neuropathy. 4,5 Thus, to support their postulate, it would be helpful to investigate intracranial fat herniation using orbital images, including computed tomography or magnetic resonance imaging, and to evaluate the optic nerve function using funduscopic examination, visual field testing, and color vision testing in patients with concurrent active TAO and subconjunctival fat prolapse. We believe that the presence of intracranial fat prolapse or compressive optic neuropathy may support their postulate.

\section{Disclosure}

The author reports no conflicts of interest in this communication.

\section{References}

1. Chatzistefanou KI, Samara C, Asproudis I, et al. Subconjunctival orbital fat prolapse and thyroid associated orbitopathy: a clinical association. Clin Interv Aging. 2017;12:359-366.

2. Glover AT, Grove AS Jr. Subconjunctival orbital fat prolapse. Ophthal Plast Reconstr Surg. 1987; $3(2): 83-86$. 
3. Putterman AM. Surgical treatment of dysthyroid eyelid retraction and orbital fat hernia. Otolaryngol Clin North Am. 1980;13(1):39-51.

4. Jeon C, Shin JH, Woo KI, Kim YD. Clinical profile and visual outcomes after treatment in patients with dysthyroid optic neuropathy. Korean J Ophthalmol. 2012;26(2):73-79.
5. McKeag D, Lane C, Lazarus JH, et al. Clinical features of dysthyroid optic neuropathy: a European Group on Graves' Orbitopathy (EUGOGO) survey. Br J Ophthalmol. 2007;91(4):455-458. 


\section{Authors' reply \\ Klio I Chatzistefanou' \\ Christianna Samara ${ }^{2}$ \\ loannis Asproudis ${ }^{3}$ \\ Dimitrios Brouzas' \\ Marilita M Moschos' \\ Elisabeth Tsianta' \\ George Piaditis ${ }^{4}$}

'First Department of Ophthalmology, National and Kapodistrian University of Athens Medical School, 'Department of Radiology, Athens General Hospital "G Gennimatas", ${ }^{3}$ Department of Ophthalmology, University of loannina, loannina, ${ }^{4}$ Department of Endocrinology, Athens General Hospital "G Gennimatas", Athens, Greece

Correspondence: Klio I Chatzistefanou

First Department of Ophthalmology, National and Kapodistrian

University of Athens Medical School, 32 Socratous Street,

16673 Voula, Athens, Greece

$\mathrm{Tel} / \mathrm{fax}+30218951722$

Email kliochat@med.uoa.gr

\section{Dear editor}

We appreciate Dr Han's comments and interest in our article. Intracranial herniation of intraorbital fat through the superior orbital fissure has been reported at an incidence of 19\% in patients with thyroid ophthalmopathy in one study, ${ }^{1}$ and its prevalence may vary between $24 \%$ and $82 \%$ in different studies $^{1-3}$ among patients with dysthyroid ophthalmopathy.

We reviewed again data from the patients' charts for symptoms and signs of compressive optic neuropathy upon presentation with subconjunctival fat prolapse. ${ }^{4}$ There were no afferent pupillary defects or optic nerve head swelling or atrophy noted on fundoscopy in any of the patients reported in this series. Clinical suspicion for possible compressive optic neuropathy, prompting paraclinical investigation with visual field testing, had been raised for patient \#2 who had a slight decrease in visual acuity to 0.9 in the right eye. Visual field testing by automated perimetry was within normal limits. Visual acuity improved to $1.0+$ in the involved eye with a change in astigmatic correction.

We also reevaluated the magnetic resonance (MR) scans of patients in the applied MR sequences: 1) T1 fat suppression, 2) STIR, and 3) T2 spin echo. We did not highlight the presence of fat located intracranially, including patients 1 , 2 , and 3 who presented with active thyroid-associated orbitopathy and subconjunctival fat prolapse.

While the possible association between subconjunctival fat prolapse and intracranial fat prolapse may raise an intriguing question, intracranial fat prolapse extending posterior to the superior orbital fissure was not noted among patients in this series.

\section{Disclosure}

The authors report no conflicts of interest in this communication.

\section{References}

1. Birchall D, Goodall KL, Noble JL, Jackson A. Graves ophthalmopathy: intracranial fat prolapse on CT images as an indicator of optic nerve compression. Radiology. 1996;200(1):123-127.

2. Jeon C, Shin JH, Woo KI, Kim YD. Clinical profile and visual outcomes after treatment in patients with dysthyroid optic neuropathy. Korean J Ophthalmol. 2012;26:73-79.

3. McKeag D, Lane C, Lazarus JH, et al. Clinical features of dysthyroid optic neuropathy: a European Group on Graves' Orbitopathy (EUGOGO) survey. Br J Ophthalmol. 2007;91(4):455-458.

4. Chatzistefanou KI, Samara C, Asproudis I, et al. Subconjunctival orbital fat prolapse and thyroid associated orbitopathy: a clinical association. Clin Interv Aging. 2017;12:359-366.

Dove Medical Press encourages responsible, free and frank academic debate. The content of the Clinical Interventions in Aging 'letters to the editor' section does not necessarily represent the views of Dove Medical Press, its officers, agents, employees, related entities or the Clinical Interventions in Aging editors. While all reasonable steps have been taken to confirm the content of each letter, Dove Medical Press accepts no liability in respect of the content of any letter, nor is it responsible for the content and accuracy of any letter to the editor.

\section{Publish your work in this journal}

Clinical Interventions in Aging is an international, peer-reviewed journal focusing on evidence-based reports on the value or lack thereof of treatments intended to prevent or delay the onset of maladaptive correlates of aging in human beings. This journal is indexed on PubMed Central, MedLine,
CAS, Scopus and the Elsevier Bibliographic databases. The manuscript management system is completely online and includes a very quick and fair peer-review system, which is all easy to use. Visit http://www.dovepress. com/testimonials.php to read real quotes from published authors. 